ny obraz zachodzących przed wiekami procesów (zastawa stołowa oraz jedzenie klasztorne) oraz te, które wymagają jeszcze dogłębnego opracowania (dietetyka i gastronomia Bizancjum). Jest to zatem pouczająca lektura dla zainteresowanych realiami życia Bizantyńczyków.

Maciej Kokoszko (UŁ) - Katarzyna Gibel (UŁ) - Łódź

\title{
Claudia RAPP, Holy bishops in late Antiquity. The nature of Christian leadership in an Age of Transition, Berkeley 2005, University of California Press, ss. 346.
}

Klaudia Rapp w książce Holy Bishops in Late Antiquity. The nature of Christian leadership in an Age of Transition proponuje nam przede wszystkim nowy model interpretacji działań, motywów i funkcji biskupów późnontycznych. Przez późny antyk rozumie czas od III do VI wieku (s. 6), jednak w wielu miejscach, czy to dla jasności wywodu, czy dla pokazania ciągłości pewnych zjawisk, sięga i po listy św. Pawła i bizantyńskie żywoty świętych z XI wieku. Już w pierwszych słowach książki proponuje następujące rozróżnienie: „Cesarz, święty mąż, i biskup; były to najpotężniejsze i najbardziej znaczące (evocative) postacie późnej starożytności” (s. 3).

Wstęp i pierwsza część pracy, złożona z trzech rozdziałów, służą wypracowaniu kategorii do opisu tych postaci. Biskup posiada pewną cząstkę władzy, którą zdobywa w określonych warunkach w określonym celu. Zarówno naturę jego władzy, jak i motywy jej zdobycia, oraz funkcję w społeczeństwie - według Klaudii Rapp - najlepiej uchwycić, jeśli porównamy go z urzędnikiem, jako reprezentantem cesarza oraz ze świętym mężem, tj. ascetą (eremitą czy cenobitą). Ponieważ „,biskup zajmuje miejsce pośrednie między dwoma biegunami przywództwa: religijnym i świeckim" (s. 6), a ponadto mamy do czynienia z okresem, w którym dopiero konstytuuje się jego rola w życiu społecznym Cesarstwa Rzymskiego, badanie wymaga - według Autorki - bardziej zniuansowanego rozumienia istoty przywództwa, niż to było dotychczas.

Następnie Klaudia Rapp wskazuje na pewne nieporozumienia, jakie często przez wielokrotne powtarzanie utrwalają się niemal w aksjomaty, z którymi potem trzeba walczyć. Tak na przykład wśród nowożytnych kościelnych historyków powszechne jest opisywanie czasów apostolskich jako złotego wieku, w którym wspólnoty charyzmatyczne idealnie radziły sobie $\mathrm{z}$ napięciami społecznymi, a biskup $\mathrm{w}$ sposób spontaniczny, wykonywał jak najlepiej swą funkcję. Dopiero potem nastąpić miała formalizacja i hierarchizacja struktury kleru (II-III wiek), zwiększenie liczby i zakresu publicznych obowiązków biskupów (dzięki łasce Konstantyna), a przez to wzrost politycznej ich roli. To wszystko prowadziło jakoby do upadku ducha, utraty charyzmatu etc. Autorka zwalcza tu także inne, podzielane przez wielu przekonanie, że biskupi przejęli władzę po urzędnikach cesarskich na skutek ,upadku kultury miejskiej charakterystycznego dla końca Cesarstwa Rzymskiego" (s. 9).

$\mathrm{Na}$ bardziej podstawowym poziomie autorka widzi dwa założenia, ograniczające wartość dotychczasowych opracowań: chronologiczne i ideologiczne. 
Pierwsze z nich opiera się na przekonaniu, że decyzje Konstantyna zapoczątkowały proces, w którym biskup stał się urzędnikiem cesarskim tracąc charyzmat Ducha Świętego. Drugie, ściśle rozgraniczające ,religijne i świeckie aspekty roli biskupa" (s. 13), miało służyć badaczom do prześledzenia zakresu politycznej i społecznej władzy kleru. Rapp stara się - jak wielokrotnie podkreśla - „niuansować" taki obraz władzy biskupiej. W tym celu powołuje do istnienia trzy nowe kategorie: autorytetu duchowego, ascetycznego i pragmatycznego. Stają się one podstawą tego, co Rapp nazywa nowym modelem wyjaśniającym. Autorytet duchowy otrzymuje konkretna, wybrana jednostka, z zewnątrz od Ducha Świętego, i nie musi on być powszechnie rozpoznawalny (s. 16). Autorytet ascetyczny różni się od duchowego tym, że zdobywa się go własnym wysiłkiem, poprzez askesis - ćwiczenie w doskonałości duchowej; autorytet ten jest przy tym powszechnie dostępny i wyraźnie „widoczny” . Pragmatyczny autorytet (od pragma-czyn) opiera się na działaniu dla dobra innych, poprzez sprawowanie funkcji publicznych oraz przyjmowanie społecznie użytecznych ról, a podstawą tych działań jest pozycja społeczna i bogactwo (s. 17).

Autorka wyróżnia spośród tych trzech kategorię autorytetu ascetycznego, ponieważ to dzieki niej możliwe jest wyjaśnienie różnicy między dwiema pozostałymi, a dialektycznie związana jest z kategorią autorytetu duchowego, który jest zarówno warunkiem, jak i znakiem istnienia autorytetu ascetycznego. Jednak autorytet duchowy może występować i bez ascetycznego - jest bowiem przekazywany biskupowi w rytuale święceń na mocy tradycji apostolskiej. W ten sposób te dwie kategorie służą odróżnieniu świętego męża i biskupa. Święty mąż zdobywa autorytet duchowy przez jawną praktykę cnót ascetycznych, a biskup otrzymuje autorytet duchowy na mocy tradycji. Biskupi jednak, przejmują także część zachowań ascetów po otrzymaniu urzędu. To roszczenie biskupów do posiadania autorytetu ascetycznego jest tym, co odróżnia ich od urzędników świeckich: „W przeciwieństwie do przywódców świeckich, pragmatyczne działania biskupów na rzecz społeczności są traktowane jako manifestacja ich ascetycznego autorytetu" (s. 18).

Kolejne trzy rozdziały pierwszej części omawiają autorytet pragmatyczny, duchowy i ascetyczny: nazwy kategorii służą zarazem za tytuły rozdziałów. Autorka korzysta tu przede wszystkim ze źródeł literackich. Dopiero druga część książki, w odpowiada w istocie, treściowo jej tytułowi i stanowi historyczną monografię biskupiego urzędu w późnej starożytności. Korzystając głównie z prac historyków starożytnych, źródeł nor matywnych i materiału epigraficznego, Rapp opisuje najpierw sposoby postępowania biskupów na podstawie analizy dwóch przykładów: Synezjusza z Cyreny i Teodora z Sykionu (rozdział 5), następnie analizuje na podstawie źródeł pochodzenie, wykształcenie, stan majątkowy i ugruntowanie w saeculum członków kleru (rozdział 6), potem zajmuje się miejscem, jakie biskupi zajmowali w przestrzeni miejskiej oraz ich niezwykle ważną rolą patronów biednej i odrzuconej części społeczeństwa (rozdział 7). Rozdział 8 traktuje o zakresie i praktyce sprawowania funkcji urzędniczych i reprezentacyjnych z naciskiem na dokładne ustalenie zakresu władzy sądowniczej, referując 
przy tym ciekawe problemy interwencji na dworze oraz problem biskupich podróży czy kompetencyjnych sporów ze świętymi mężami. Rozdział 9 konfrontuje dotychczasowe ustalenia Autorki z mitem o upadku kultury miejskiej: Rapp dąży tutaj do kompleksowego określenia społecznej roli biskupa w kontekście zmian w sposobie zarządzania Cesarstwem Rzymskim, uwidaczniającym się zwłaszcza za panowania Justyniana.

Należy tu jednak zwrócić uwagę na kilka ważnych i bardziej szczegółowych zalet pracy naszej Autorki. Argumentacja obalająca przekonanie o zmniejszającej się liczbie curiales wydaje się być wyjątkowo skuteczna. Autorka zdaje sobie doskonale sprawę z wymowności takich źródeł, jak tekst Libaniosa mówiący o tym, że curia liczyła niegdyś 600, a za jego życia już tylko 60 członków (s. 284), co jednak thumaczy retoryczną przesadą. Zwraca również uwagę na fakt kumulacji bogactwa w rękach nielicznych osób, przy równoczesnym pogarszaniu się dystrybucji dóbr materialnych: doprowadziło to do sytuacji, w której w miastach rządzi $\mathrm{w}$ istocie niewielu bogatych członków kurii, co da się zauważyć już w IV wieku. Dowodem na to jest nie tylko nowa interpretacja źródeł literackich, syryjskjch czy egipskich, ale także epigraficznie potwierdzona zmiana tytulatury członków kurii widoczna również na Zachodzie (z decuriones na pricipales curiae czy possesores) (s. 286). Zdanie Libaniosa miałoby znaczyć po prostu, że tylko 60 członków kurii w tym czasie stać było na liturgie, i to oni zarządzają miastami, reszta odgrywała rolę ważną jedynie dla statystyki.

Oryginalny i trafny jest w książce opis fenomenu pustyni (s. 105-125), bardziej kontrowersyjne już opracowanie tezy o modelowej roli Mojżesza w życiu starozytnych świętych (s. 125-136). Rapp udaje się skutecznie uzasadnić swoją polemikę ze spotykanym w literaturze przekonaniem o ścisłej dychotomii miasto/ pustynia. Jej analiza źródeł hagiograficznych i epigraficznych ukazuje, jak nośnymi i przemawiającymi do wyobraźni obrazami były przekształcanie pustyni w ogród dzięki pracy i cnocie mnicha, oraz przekształcanie pustyni w miasto. Dychotomia pustynia/miasto pokrywała się z dychotomią mnich/biskup. Rapp dowodzi, opierając się na ustaleniach P. Browna, jak często asceta stawał się również „nosicielem” autorytetu pragmatycznego. Ta linia rozumowania kontynuowana jest także w innych rozdziałach. Autorka podkreśla, że i mnisi mieli władzę sądowniczą, podobną do biskupów, że i oni równie skutecznie interweniowali na dworze: przysługiwała im więc, podobna do biskupów, parrhesia (s. 260-273). U podłoża tej polemiki leży obserwacja, że asceci zostawali także biskupami, i że biskupi zmieniali tryb życia na bardziej ascetyczny dostępując takiej godności, jak np. Ambroży i Augustyn, choć nie uczynił tego Synezjusz z Cyreny. Te wszystkie bogato udokumentowane w źródłach tezy dają nam bardziej rzeczywisty obraz relacji mnichów i kleru.

Claudia Rapp zauważa analogię pomiędzy biografiami starożytnych biskupów oraz pierwszego ascety Mojżesza. Nawet kolejne etapy życia: świecką edukację, ucieczkę w samotność na pustynię, sprawowanie przywództwa religijnego i społecznego włączali nierzadko hagiografowie w cursus honorum, jakby szli za 
wzorem proroka. Dowodzenie takiej hipotezy napotyka w moich oczach na przeszkodę nie do przekroczenia. Otóż życie świętych znamy przede wszystkim z historii kościelnych i hagiografii. Wykształcenie modelu strukturalnego hagiografii pod koniec IV wieku, o którym pisał P Nehring (Topika wczesnych łacińskich żywotów świętych, Toruń 1999), skutkuje natychmiastową erupcją imitacji. Nehring wskazuje, że w analizowanych przez niego żywotach postacią znaczącą dla twórców gatunku, jako pre-asceta był Eliasz. Łatwo jednak zgodzimy się z Rapp, że dla częściej branych przez nią pod uwagę świętych biskupów, jako przywódców ludowych z przeszłością ascetyczną, oczywistym typem był Mojżesz. Widać to już w pierwszym antycznym żywocie świeckiego chrześcijanina, mianowicie w Vita Constantini Euzebiusza z Cezarei, gdzie życie cesarza jest wpisane w strukturę biografii Mojżesza: podkresla się przy tym zalety cesarza jako opiekuna (episkopos) Kościoła (por. A. Cameron, Eusebius' Vita Constantini and the constructions of Constantine, w: Portraits. Biographical representation in the Greek and Latin literature of the Roman Empire, ed. M. Edwards - S. Swain, Oxford 1997, 145-174).

Wydaje mi się, że należałoby zmodyfikować szatę słowną: wiemy na pewno, że pierwsi autorzy żywotów oryginalnie wplatali losy swoich bohaterów w krosno Pisma Świętego, korzystając z wypróbowanych i znanych powszechnie wątków, a ich naśladowcy przejęli to jako dobrze działającą metodę pisania biografii. Ale czy ktoś naprawdę może zakładać, że Augustyn celowo najpierw terminuje u faraonów manicheizmu, następnie poświęca się życiu w ascezie z przyjaciółmi, aby zostawszy biskupem móc podkreślać paralelę losów własnych i Mojżesza? Czy nie wspomniałby o tym, choćby przelotnie, w swoich Wyznaniach? Wątpliwe też, by Konstantyn znał losy Mojżesza, co do których jego biograf Euzebiusz był doskonale poinformowany. Są miejsca z których wynika, że Autorka tak właśnie może rozumieć tę analogię. Dla pełnej jasności wypadałoby ją osłabić i mówić nie o świętych, którzy a priori wybierali model życia Mojżesza, ale o ich biografach, którzy z właściwym starożytności wyczuciem literackim dokonali a posteriori interpretacji ich życia.

Nowy model interpretacyjny Klaudii Rapp z trzema kategoriami autorytetu: duchowego, ascetycznego i pragmatycznego pozwala pewnością lepiej ująć złożoność roli biskupa w świecie antycznym, jednakże irytuje nieco chęć aplikacji tej teorii w miejscach, w których nie jest to konieczne. Można by rzec, że siła spekulatywna bierze niekiedy górę nad racjonalnością krytyczną historyka. Na przykład, w rozdziale dotyczącym autorytetu duchowego Autorka w dłuższym passusie omawia występowanie w literaturze patrystycznej, począwszy od Klemensa Aleksandryjskiego i Orygenesa, terminów christophoroi - nosiciele Chrystusa i pneumatophoroi - nosiciele Ducha (s. 57-60). Same nazwy, owszem, wskazują na pewną możliwą różnicę desygnatów, ale już używanie terminu pneumatophoros przez Ojców Kościoła nie poddaje się tak jednoznacznym kategoryzacjom, jak chciałaby tego Rapp. Jej podsumowanie, w którym christophoroi stają się nosicielami autorytetu ascetycznego, a pneumatophoroi duchowego, zapewnionego biskupowi przez sukcesję apostolską, zbyt silnie próbuje dostosować rze- 
czywistość do nowego modelu wyjaśniającego, działając w ten sposób wbrew wyznaczonemu celowi: zamiast niuansować, upraszcza (por. np. A. Guillaumont, „Uduchowieni” $i$ ich relacje $z$ hierarchia kościelna $w$ chrześcijaństwie wschodnim pierwszych wieków, w: tenże, U źródel monastycyzmu chrześcijańskiego, t. 2, thum. S. Wirpszanka, Tyniec - Kraków 2006, 227-237. Autor ten wskazuje, że „starszych” we wspólnocie pachomiańskiej, czyli doświadczonych ascetów, którzy dzielili się z uczniami swoim doświadczeniem, określano mianem pneumatophoroi.

Wydaje się też, że w tym celu w rozdziale 7, można by więcej uwagi poświęcić zagadnieniu synodów biskupich oraz rozważyć kwestię ich podobieństwa do instytucji rzymskich (por. W. Myszor, Chrześcijanie w cesarstwie rzymskim II i III wieku, Katowice 2005, 76-78; E. Wipszycka, Kościót w świecie późnego antyku, Warszawa 2006, 44-49, spec. 46), wskazać na możliwość uczestniczenia w nich ludzi spoza hierarchii kościelnej, podkreślić ważną rolę synodów w odpieraniu herezji i integracji biskupów zarówno wewnątrz instytucji, jak i we wspólnym nauczaniu doktryny.

Autorce i redaktorom omawianej książki nie udało się w tej obfitości materiału uniknąć kilku niejasności. Dosyć często pisze ona o biskupach, opierając się na źródłach, które mówią tylko o kapłanach. Nie tyle jest to błąd, co skrót myślowy, który można by łatwo ominąc tłumacząc się w stosownym miejscu z takiej metonimii. I tak np. na stronach 46-47, opierając się na świadectwie Jana Chryzostoma, Rapp opisuje, jak w funkcjach liturgicznych biskupa zawiera się jego duchowy autorytet, choć w tekście źródła ani razu nie pada słowo „biskup”. Poza tym, na stronę 40 wkradła się dwuznaczność związana z rozróżnieniem Pseudo-Augustyna od Ambrozjastra, podczas gdy chodzi o tego drugiego, tj. autora zarówno Komentarza do Pierwszego Listu do Tymoteusza, jak i Pytań do Starego i Nowego Testamentu, jak to podają przypisy na tej stronie.

Praca Klaudii Rapp to niezwykle ważna synteza, której największą zaletą jest stworzenie nowego teoretycznego paradygmatu, wyjaśniającego rolę biskupa w starożytnym Kościele. Dzięki temu zrealizowany zostaje główny cel autorki, czyli stworzenie bardziej zniuansowanego obrazu stosunków między biskupem a światem, w którym żył, ze szczególnym uwzględnieniem świętych mężów, oraz cesarza i lokalnych reprezentantów jego władzy. Niemałe znaczenie odgrywają też oryginalne próby rozwiązania pewnych spornych, bądź zbyt jednoznacznie przedstawianych kwestii, jak choćby związku rozwoju episkopatu z upadkiem miast, czy użycia toposu pustyni w tekstach literackich. Wielkich zalet tej książki nie przysłaniają jednak pewne jej braki i wady, wynikające najczęściej ze znanej umysłom spekulatywnym pokusy dostrzegania całkowitej kongruencji faktów $\mathrm{z}$ ideami i rzeczywistości z teorią. 